\title{
The effect of work discipline and motivation toward civil servant's performance in kerenci regency regional secretariat
}

\author{
Beni Setiawan ${ }^{1}$, Syamsir ${ }^{2}$, Afriva Khaidir ${ }^{3}$ \\ 123Universitas Negeri Padang, Padang - Indonesia, ( benisetiawan15208036@gmail.com)
}

\begin{abstract}
This study aims to reveal the effect of work discipline motivation on civil servants performance working at Kerinci Regency Regional Secretariat. because there is a problem the employee performance it is proven by preliminary data that researchers get there are still targets that have not been fully realized. This research used quantitative method. The population of this study was all civil servants serving in the Kerinci Regency Regional Secretariat. Respondents in this study were amounted to 95 samples. The data collection technique used in this study was proportional stratified random sampling technique. The data was collected through questionnaires that have been tested of their validity and reliability in advance, both the content and empirical test items in the field. Data analysis technique used in this research was multiple regressions. The results showed that there is a significant effect of work discipline and motivation on Kerinci Regency Regional Secretariat civil servants performance. This means that higher-level work discipline and motivation will improve civil servants performance.
\end{abstract}

Keywords: work discipline, work motivation, performance

\section{Introduction}

In organizing government and development activities, the role of civil servants is very important, because they implement government and development in an effort to achieve national goals. Human element is one important element, because humans always play an active role in an organization.

Human resources play a very important and strategic role for the achievement of organizational goals in the government. This is because humans are the planners, actors, and determinant of the realization of the organization's goals even though the infrastructure and other resources are sufficient. Therefore, in order for the implementation of organizational duties in the government can run effectively, efficiently and optimally, it requires human resources development in a planned and sustainable way as to obtain competent, professional human resources and capable of having high quality performance in accordance with the demands of the organization and are expected to be an example to societies.

In order to achieve the goals of an organization, good employees' performance is necessary. A performance can be said to be good if in doing a job, one cat get results in accordance with goals both in quality, quantity and time in accordance with targets that have been determined. This is in line 
with the opinion according Mangkunegara (2000: 67) saying that performance is quality and quantity works achieved by employees in performing their duties in accordance with the responsibilities given to them.

Kerinci Regency Regional Secretariat as an institution that has the task of assisting the Regent in carrying out his duties as the administration of the government, whether it is in the administrative, organizational and administrative tasks and provide administrative services, which was established based on Kerinci Regency Decree No 13/2011, on the Regional Secretariat Organization and the Secretariat of the Regional People's Representative Council of Kerinci and Kerinci Regent Decree No 10/2011 dated June 13, 2011 on the Description of the Main Duty, Function and Administration of the Regional Secretariat of Kerinci Regency.

Kerinci Regency Regional Secretariat consists of several sections: Public Administration, Legal, Public Relations and Protocol Section, Economic Administration Section, Development Administration Section, Public Welfare Administration Section, General Section, Organization Section, Electronic Data Processing (PDE) Section and Satelda, each of which is carried out by Assistants: the Government Assistant, the Assistant for Economy and Development, the General Administrative Assistant.

Based on preliminary data obtained by the author, when doing initial research in Kerinci Regency Regional Secretariat, the author found some problems of civil cervants' performance in Kerinci Regency Regional Secretariat. This is marked by the still-unfulfilled job target. This is due to some employees in the Kerinci Regency Regional Secretariat which are still lack of discipline. It is also related to the lack of work motivation. It can be said that problematic because based on Government Regulation No. 46/2011 on the assessment of employees' performance targets, that a job done can be said good if the target can be fully realized.

In producing the optimal performance, it requires work discipline for organizational goals to be achieved. According to Hasibuan (2008: 168), discipline is the awareness and willingness of an employee to obey all the prevailing rules and norms in a government organization. Given this theory, it will encourage passion or morale, and encourage the realization of organizational goals. The same thing is also expressed by Prasetyo (2008: 36) who says that one of the determinants of the effectiveness of performance is work discipline. Employees with high spirits feel that they include organizational goals worthy of attention and that their efforts are recognized and respected. Highly enthusiastic employees provide a positive attitude, such as loyalty, joy, cooperation, pride in service and obedience to obligations. Attendance or absenteeism can be one of information about the level of employee discipline. If there are many employees who do not work for unclear reasons or skipping work, it indicates the lack of discipline on the employee. Based on obtained that, it can be seen that the number of employees at the Kerinci Regency Regional Secretariat go missing without information, high numbers of working trip. The high number of employees who are not present without information can lead to less optimal employees' performance.

In addition to work discipline, work motivation can also affect performance as revealed by Robert Kreitner and Anglo Kinicki (2001: 205). They say that work motivation can certainly affect performance, though not the only factor that shapes performance. Robbins in Wibowo (2014: 322) states that work motivation is a process of individual intensity, direction, and persistence toward the achievement of goals. In improving employees' performance, work motivation factor from superiors is very important. Motivation becomes a motivator for a person to carry out activities in order to get the best results. Meanwhile, Greenberg and Baron (2003: 190) argue that work motivation is a series of processes that arouse, directed, and maintain human behavior toward achievement of goals.

Therefore, based on the phenomenon that has been described above, on the issue of undisciplined employees and low motivation of work, the author is interested to conduct further research on employees' performance at Kerinci Regency Regional Secretariat, by identifying and examining 
various factors that affect employees' performance entitled "The Effect of Work Discipline and Motivation toward civil servants' performance in Kerinci Regency Regional Secretariat Office".

\section{Method}

The method used in this research is quantitative method. The dependent variable used was civil servants' performance while the independent variables are work discipline, andwork motivation. In this study the operational definition of variables are as follows:

1. Performance Variable (Y). Performance is the result of work that has been achieved in accordance with the responsibilities given to a civil servant in a certain period. The indicators are (Masrukhin, Waridin, 2004: 92): (a) quality, (b) timely manner, (c) effectiveness, (d) independence, (e) work commitment

2. Work Discipline Variable (X1). The attitude of a civil servant who voluntarily obeys all rules and norms applicable within an organization. The indicators are (Syadam 2005: 284) (a) attendance, (b) responsibility, (c) attitude, (d) norm.

3. Work Motivation Variable (X2). It is the effort to mobilize human resources to be productively managed and to achieve goals desired by the organization. The indicators are (Edward Muray "Mangkunegara 2005") (a) job well done, (b) do something with the goal of achieving success, (c) accomplish tasks that require effort and skill, (d) desire to be famous and (e) do the difficult with satisfactory results, (f) do something very meaningful, (g) do something better than others

In this study, the population is all 123 employees at Kerinci Regency Regional Secretariat Office. The sample was obtained by using Slovin's which resulted in 95 people short-listed. For determination of sample in this research, stratified random sampling technique was used. It is a sampling technique taken from each subpopulation at random based on proportion of employees' rank in every subpopulation. As for getting the required data, it was obtained through questionnaire. The type of data collected in this study was taken from two sources, namely primary data and secondary data.

Primary data in this study were questionnaires from civil servants working at the Kerinci Regency Regional Secretariat Office. Meanwhile, the secondary data which was used to support primary data came from the organizational part of Kerinci Regency Regional Secretariat Office, attendance, performance accountability report of government agencies (LAKIP) Kerinci Regency Regional Secretariat Office 2015, journal, online news (Kenali.com), literature study and references related to the research.

\section{Result and Discussion}

After getting the results of research and regression equation test, the discussion in the findings of this study are as follows:

1. The Effect of Work Discipline toward civil servants' performance in Kerinci Regency Regional Secretariat Office.

Based on the test results of the effect between work discipline and performance, it was found that work discipline variable has a positive and significant effect on civil servants' performance in Kerinci Regency Regional Secretariat Office. This can be proven by the result of data processed using SPSS 18 software, that there is significant effect between work discipline on employees' performance at Kerinci Regency Regional Secretariat Office with F count equal to 1,478 and Deviation From Linierity is $0,174>0,05$. As the value of significance is greater than the Alpha (0.05), it can be concluded that work discipline variable and performance is linear. The amount of influence of the work discipline variable on performance is equal to $7.7 \%$. 
Based on these results, it can be concluded that work discipline can affect employees' performance at Kerinci Regency Regional Secretariat Office and is able to affect employees' performance significantly. This means that better employee work discipline will be able to improve employees' performance, and vice versa. Thus, the findings in this study fit and strengthen the theory put forward by Prasetyo (2008:36) which states that one of the determinants of performance effectiveness is work discipline. The results of this study also reinforce the theory put forward by Hasibuan (2014: 193), that discipline is the awareness and willingness of an employee to obey all the rules of an institution and prevailing social norms, so that he can produce good performance.

Based on the results of research and theories by experts used in this study, which is related to the efficiency of work discipline toward performance, it can be concluded that better employees discipline will be able to improve employees' performance, and vice versa.

2. The Effect of Work Motivation toward civil servants' performance in Kerinci Regency Regional Secretariat Office.

Based on the test results of the effect between work motivation and performance, it was found that work motivation variable has a positive and significant effect on civil servants' performance in Kerinci Regency Regional Secretariat Office. This can be proven by the result of data processed using SPSS 18 software, that there is significant effect between work motivation on employees' performance at Kerinci Regency Regional Secretariat Office with F count equal to 0.653 and Deviation From Linierity is $0.174>0.05$. As the value of significance is greater than the Alpha (0.05), it can be concluded that work motivation variable and performance is linear. The amount of influence of the work motivation variable on performance is equal to $5.8 \%$.

Based on these results, work motivation can affect employees' performance at Kerinci Regency Regional Secretariat Office and is able to affect employees' performance significantly. This means that better work motivation received by employees will be able to improve their job satisfaction, and vice versa. The findings are also reinforced by Robert Kreitner and Anglo Kinicki (2001: 205) who revealed that work motivation may certainly affect performance even if it is not the only factor that shapes performance. This research is also reinforced by other research such as one conducted by Ana Nor Andriana (2015) who says that motivation have a significant effect on employees' performance and a research conducted by Surianti (2015) that work motivation has positive and significant influence on performance. It further reinforces by Johanes Eliezer Ayer's (2016) research stating that motivation has a positive and significant effect on civil servants' performance working at Supiori Regency Agriculture Office. Thus, the findings in this study are appropriate and accordance with the theory expressed by King (2005: 24) that work motivation has a significant effect on employees' job satisfaction, so the findings in this study can strengthen the theory.

Based on the results of research and theories by experts used in this study, which is related to the efficiency of work motivation toward performance, it can be concluded that better employees motivation will be able to improve employees' performance, and vice versa.

3. The Effect of Work Discipline and Motivation toward civil servants' performance in Kerinci Regency Regional Secretariat Office

Based on the test results between work discipline and work motivation variables on civil servants' performance in Kerinci Regency Regional Secretariat Office ( $\mathrm{F}$ test), there is a simultaneous significant effect between work discipline (X1), work motivation (X2) on civil servant's performance (Y) at Kerinci Regency Regional Secretariat Office with a significance value of $0.000<0.05$. In addition, the $R$ Square value of 0.287 can be interpreted that the two independent variables of this study have an effect of $28.7 \%$ on the dependent variable. 
Based on this result, work discipline and motivation provide significant effect toward civil servants' performance in Kerinci Regency Regional Secretariat Office and are able to influence their performance significantly. In other words, the higher work discipline and work motivation felt by employees at Kerinci Regency Regional Secretariat Office, then their performance will be better and vice versa.

\section{Conclusion}

Based on the results of hypothesis testing to determine the effect of leadership, work motivation, compensation and discipline toward Civil Servants' Performance in Kerinci Regency Population and Civil Registration Office, it can be concluded that:

1. There is a significant effect of work discipline toward civil servants' performance in Kerinci Regency Regional Secretariat Office with a contribution of 7.7\%. It means that work discipline can affect performance. In order gain good civil servants' performance in Kerinci Regency Regional Secretariat Office; it requires the implementation of good work discipline as well.

2. There is a significant effect of work motivation toward civil servants' performance in Kerinci Regency Regional Secretariat Office with a contribution of 5.8\%. It means that work motivation can affect performance. In order gain toward civil servants' performance in Kerinci Regency Regional Secretariat Office; it requires the implementation of good work motivation as well.

3. Work discipline (X1), and work motivation (X2) simultaneously affect civil servants' performance $(\mathrm{Y})$ in Kerinci Regency Regional Secretariat Office.

Based on above conclusions, then the author gives suggestions as follows:

1. It is recommended that the managements at Kerinci Regency Regional Secretariat Office to pay more attention to work discipline, work motivation and job satisfaction of employees, so that their performance can be better.

2. For further researchers, it is advisable to conduct further research related to employee performance by incorporating new theories and examining other factors that can affect employees' performance.

\section{References}

Gibson, James,L. (2000). Organisasi, Perilaku, Struktur dan Proses. Edisi ke-5. Cetakan ke-3. Jakarta: Penerbit Erlangga.

Greenberg, Jerald dan Robert A. Baron. (2003). Behavior in Organizations. New Jersey: Prentice Hall Hasibuan, Malayu. (2014). Manajemen, Dasar Pengertian dan Masalah. Jakarta: Bumi Aksara

Hessel, Nogi Tangkalisan. Manajemen Publik, Jakarta: Grasindo, 2007

Kreitner, Robert abd Anglo Knicki , (2001). Organizational Behaviour . Fith Edition.

Mangkunegara, Anwar Prabu. (2005). Evaluasi Kinerja SDM. Jakarta: Penerbit PT. Refma Aditama

Robbin, P, Stephen. (2001). Perilaku Organisasi, Konsep, Kontroversi, Aplikasi, Jilid I dan II, Edisi Kedelapan, Jakarta: Prenhallindo.

Sugiyono. (2011). Metode Penelitian Kuantitatif, Kualitatif Dan RED. Bandung:Alfabeta.

Peraturan Pemerintah Nomor 53 Tahun 2010 Tentang disiplin pegawai negeri sipil

Peraturan Pemerintah Nomor 46 Tahun 2011 Tentang penilaian prestasi kerja pegawai negeri sipil 